\section{OPENING OF NEW LABORATORIES AT UNIVERSITY COLLEGE, LIVERPOOL.}

THE great interest which the manufacturers of Liverpool take in the University College of that city was again exemplified by the opening of the new William Gossage laboratories a few days ago, briefly referred to in our Educational Intelligence last week. Since the college was founded, it has tad the ready and full support of the manufacturers and traders of Liverpool and the district around, the result being that today it is in the front rank of institutions for higher education. With well-equipped laboratories, and a strong professoriate, the college possesses exceptional opportunities for study and research; and the work accomplished in it has done much to advance the arts as well as the sciences. The teaching course, which extends over four years, not only aims at training students for manufacturing pursuits, but also to carry out independent investigations.

The first section of the chemical department of the college was opened in May 1886. But the main laboratories, the most important of all, were not at that time proceeded with, partly owing to lack of funds, and partly because a portion of the site, the whole of which was given by the Corporation of Liverpool. was not then vacant, and could not be transferred to the college until later. In the early years the advanced students were necessarily few in number, and there was sufficient accommodation for them as well as for much larger junior classes; but by the year I 893 the want of a complete laboratory for the whole of the special laboratory students was seriously felt.

In these circumstances Mr. F. H. Gossage and Mr. T. Sutton Timmis generously undertook jointly to build and fit up a further section of the building, including the largest of the main laboratories and rooms below, at a cost of $7000 \%$, and to present them to the college as a memorial of the late Mr. William Gossage. Other portions of the buildings are being erected by public subscription, the list being headed by donations of I000/. each from Sir John T. Brunner, M.P., Mr. E. K. Muspratt, and Messrs. Lever Brothers.

Mr. William Gossage, whose name is enshrined in the new laboratories, was one of the most fertile inventors of this century. His work was mainly chemical, and before his death in 1877 he possessed no less than sixty-three patented processes. In the early days of the soda industry, the hydrochloric acid gas, which is evolved from common salt for the production of sulphate of soda, was poured into the air in enormous volumes, to the destruction of vegetable and injury of animal life. In 1863 the Earl of Derby was instrumental in passing into law the Alkali Act which compels manufacturers to condense all except a very small fraction of the hydrochloric acid gas which they produce. It was William Gossage who rendered this legislation practicable by inventing the tall stone condensing towers which are so prominent a feature of the landscape in every Leblanc alkali works' district, and by means of which what was before worse than wasted is turned into a source of considerable profit to the manufacturers.

In 1838 he was engaged in experiments for the recovery of sulphur lost in the alkali waste of the Leblanc process, and also for the manufacture of soda from sodium sulphide. It was at this time that he demonstrated that calcium sulphide, and also sodium sulphide in solution, are decomposed by the action of dilute carbonic acid produced in lime kilns. In 1854 he produced silicate of soda or soluble glass by fusing sand with soda. He also utilised the red liquors from carbonate of soda manufacture, which were at that time an almost waste product, producing from them caustic soda, which was for years the only caustic soda made, and was employed to facilitate the manufacture of soap. He thus introduced what has now become a large and important industry in caustic alkali. In many other directions his inventive mind found occasional diversion, and of him it may be truly said that, although he was a successful manufacturer, he spent his mental energy and his means seeking out many inventions which benefited others rather than himself.

The new buildings, opened on December 12 , include a large laboratory 60 feet by 32 feet, with benches fitted up for forty-four advanced students, an adjacent room provided with a new form of heated sand bath and other appliances for the service of the main laboratory, and, in the basement, an additional lecture room to seat seventy or eighty, a preparation room, and a gas analysis room. These five rooms, which are lined with ivory glazed bricks, constitute the "William Gossage" laboratories.
The other new buildings are a metallurgical laboratory, with furnaces and other equipment, an important addition to the research laboratory, a store for apparatus and chemicals, a dynamo room, electric-accumulator room and a heating chamber.

Beyond a number of minor improvements in the main laboratory, the benches do not essentially differ from those in some other similar laboratories except in one important respect, that the half-closed chambers placed in the middle of each bench have a really efficient draught which carries away all fumes from small operations without allowing any to escape into the room. This result is attained by carrying the whole ventilation of the room, which normally amounts to 125,000 cubic feet per hour through these students' fume chambers and the larger chambers on either wall ; the foul air passes from these hoods down to a wide subterranean channel ending at the base of a tall up-cast shaft, where a coke fire maintains a strong draught ; by no other way can air escape from the laboratory, while a fan forces washed and warmed fresh air through flues and gratings in the walls into the room, so as to maintain a constant pressure during the working day.

The laboratories will be opened to students on January 7 , I 897 , and the committee will be glad to receive further dona. tions to enable them to finish the buildings, and furnish the necessary equipment.

\section{THE ANTHROPOLOGICAL HISTORY OF SOUTHERN RUSSIA.}

$\mathrm{I} \mathrm{N}$ continuing his ethnographic history of the region between the Dniester and the Caspian in the Bulletins de la Socitté d'Anthropologie, vii. (4 sér.), I896, M. Zaborow'ski commences by criticising Sergi's assertion that "the first colonists of Southern Russia came from the Mediterranean." The enthusiastic Italian anthropologist recognised skulls of the type of his Mediterranean race from ancient graves in several parts of Russia, but Zaborowski contends that he has not paid sufficient attention to the dates of the finds, and that he has neglected the culture evidence. The author reserves the term Aryan to the tall blond dolichocephalic race, that is solely of European origin, which is not the case for the brown dolichocephalic Mediterranean race or the Celto-slavic type. Aryan languages are spoken in Europe where the brown brachycephals and dolichocephals have never penetrated, at least until our epoch ; but there are no people with an Aryan language who have not come into contact with the fair race.

In the most ancient graves of the bronze age, Neolithic dolichocephals are still generally to be found, but before the Scythian epoch there was a mingling of brachycephals, perhaps partly through commercial relations and partly from women captured in war. The original home of the Scythians was to the east of the Caspian. The finds in the Scythian tombs exactly correspond to the description given by Herodotus of their neigh. bours, the allied Massagetes, except that iron is not quite unknown. The Thyssagetes, Tyregetes, Getes and Dacians, arose from the Scythians and Massagetes, descendants from the Getes and Dacians, still exist among the Roumanians, having harsh black hair and a yellow-brown complexion. In Scythia, Herodotus mentions the large nation of the indigenous, nomadic Budins, who "have remarkably blue eyes and red hair." These may be the ancestors of the Finns, at all events they formed a contrast to the Scythians, to whom Hippocrates attributed a short stature and a brown skin.

The Scythian period was terminated by the arrival of the Goths in the second century A.D. Strabo does not know of them, Tacitus mentions their occupying the shores of the Baltic between the Elbe and the Vistula. Later they came down the latter river to the Black Sea, and reached the lower Danube; at the commencement of the third century this enterprising and warlike nation touched the eastern borders of the Roman empire. The Goths were described as very large, of fine appearance, fair hair, milk-white skin, with great moral energy, modest, and very strong. They spoke a German dialect, and were even in possession of the primitive runic alphabet. The arrival of the Goths at the Black Sea is a return of the European blonds to a region where the brown Asiatic Scythians had reigned as masters for centuries.

M. Zaborowski evidently believes that the Aryan language arose about the Black Sea. He, with Broca and others, accepts the tradition that the Cymbri of Jutland were the descendants of

NO. I 417 , VOL. 55$]$ 
the Cimbrians of the Cimmerian Bosphorus, driven to the west of Europe by the Scythian invasion in the seventh century B.C. These Cymbrians had already had relations with the Greek world, for the Greeks had established colonies and introducer metals and the cultivation of the soil in Southern Russia before the arrival of the Scythians, and they may be regarded as the importers of the dialect from which the German languages arose. They were of the same race as the Neolithic blonds.

The Goths were driven away from the northern borders of the Black Sea by the Huns before the end of the fourth century; but though they remained during only two centuries, traces of their stay hąve been discovered.

The Alains, mentioned by authors in the first century A.D., were a blond people mixed with Medes, and possibly with the Scythian Massagetes. The Ossethes sprang from these Scythian Alains, who were driven into the Caucasus after the Gothic period by the pressure of the Huns. Thus the Ossethes are essentially Aryans and Europeans, despite the Iranian and Asiatic origin of their language, these originally blond Europeans, have been intimately mingled with Scythians, and later with other Caucasians, mostly browns and brachycephals. M. Kovalewsky states that among the Ossethes, when a bride enters for the first time her husband's house, she is greeted with "Prosperity! prosperity! nine boys and a girl with blue eyes." The latter wish could never arise amongst a brown population. In his work "Droit Coutumier Osséthien" (I 893), Kovalewsky details numerous customs which, as Zaborowski points out, abundantly confirm the essentially European and Aryan origin of this nation ; and the former author compares them with those of the Greeks of Homer, the Germans of Tacitus, and with the Romans, such, for example, as the cult of the hearth-fire, household arrangements, marriage ceremonies, and burial customs.

The Armenians, like the Ossethes, are a people with their original characters modified. They were also blond, at least in great part, and even now I I per cent. are blonds according to Chantre.

In the Hindu Kush there are many traces of a fair race, and Zaborowski enters into a comparison of the Kafirs with the Ossethes, which tends to show that they are closely related.

\section{THE HORN EXPEDITION TO CENTRAL AUSTRALIA.}

THE Report on the work of the Horn Scientific Expedition to Central Australia has now been completed. It is published in four parts, the first of which is devoted to the narrative and summary of scientific results, while the three remaining parts deal respectively with zoology, geology and botany, and anthropology. The zoological results were reviewed in NATURE a short time ago (vol. liv. p. 24I), and we propose to deal with the part on anthropology in a future issue. For the present we confine ourselves to summarising the knowiedge gained of the geology and botany of the region explored, prefacing the synopsis with a statement of the inception and objects of the expedition, and of the region traversed, this introductory matter being based upon the Narrative.

\section{Objects of the Expedition.}

Mr. W. A. Horn, who defrayed the cost of the expedition to Central Australia, and through whose generosity the Report has been publisherl, deserves the gratitude of men of science. The results which he has been the means of obtaining are most valuable contributions to the knowledge of the natural history of a little-known region; and by the accumulation of these facts, gained by direct observation, many perplexing questions will be elucidated. One of these questions is referred to by $\mathrm{Mr}$. Horn in a brief introduction to the Narrative. For some time the opinion has been held that when the Australian continent was submerged the elevated portions of the McDonnell Range in Central Australia existed as an island, and that consequently older forms of life might be found in the more inaccessible parts. The scientific exploration of this belt of country was, therefore, much desired by men of science, and when Mr. Horn expressed his intention to organise and equip an exploring party, the scheme was received with great favour. In order to secure the services of the best men in Australia, the Premiers of the principal colonies were asked to nominate scientific representatives. As a result, Prof. Baldwin Spencer, Mr. J. Alexander Watt, Prof. Ralph Tate, and Dr. Edward Stirling joined the expedition, and Mr. C. A. Winnecke was chosen as surveyor and meteorologist.

The objects of the expedition as set down in the articles under which the members started were :--The scientific examination of the country from Oodnadatta to the McDonnell Range; the col. lection of specimens illustrative of the fauna, flora, and geo. logical structure and mineralogical resources of that region, and the illustration by photography of any remarkable natural features of the country traversed; the securing of photographs of the aborigines in their primitive state, the collection of information as to their manners, customs, and language, and the reproduction of their mural paintings. The expedition started in Mav I894, and returned in August of the same year, burdened with the records and the photographic spoil of the region which the members went out to see.

\section{The McDonnell Ranges}

The McDonnell Ranges are in the very centre of Australia, they are barren and rugged in the extreme, rise to an altitude of nearly 5000 feet above sea-level, while the country surrounding them has an altitude of about 2000 feet, sloping away on every side towards the coast, I000 miles distant. The mountains are at the head of the river Finke, and for this region, including the valley of the Finke, the name of Larapintine has been adopted from the native name of the Finke, "Larapinta." It was over this area that most of the explorations were conducted.

The general editor of the Report on the work of the expedition is Prof. Baldwin Spencer, who is also the author of the Narrative. Without entering into too many details, Prof. Spencer summarises, in a more or less popular form, in this part of the report, the work accomplished, and gives a good idea of the nature of the country through which the expedition passed.

\section{Nature of the Country traversed.}

It is usual to speak of the whole interior of Australia as a desert or Eremian country, but Prof. Spencer shows that this name as applied to the whole area is very misleading. It is true that over wide areas extending especially over the western half of the interior there spead out sandhills and flats covered with Mulga scrub or "Porcupine" grass, which may justly be described as desert, but in addition to this there is a vast track of country watered by streams which at varying intervals of time are swollen with heavy floods which spread out over wide tracts, and for a time transform the whole country into a land covered with a luxuriant growth of vegetation. To this part of the continent the name of the Australian Steppes has been applied. The Lower Steppes extend over the area occupied by the great Cretaceous formation with its alternating stony or gibber plains, loamy flats, and low.lying terraced hills capped with Desert Limestone. At Lake Eyre the land is 39 feet below sea-level, and gradually rises to a height of rooo feet at its northern limit. What are termed the Higher Steppes are characterised by high ridges of Ordovician and Pre-Cambrian rocks which stretch across the centre of the continent from east to west for some 400 miles. The average elevation of these Higher Steppes may be taken as about 2000 feet, and above them the higher peaks of the ridges rise for some 2500 feet more.

Prof. Spencer devotes two chapters in his Narrative to the country belonging to the Lower Steppes, two to the Higher Steppes, and one to the Desert Region. The gibber plains to which he refers consist of flat surfaces covered with a layer of purple-brown stones, varying in size from an inch to perhaps a foot in diameter, and all made smooth by the constant wearing away of wind-borne sand-grains. Judging from the description, and the views which jllustrate it, nothing could be more desolate than a gibber plain when everything is bare and dry. Throughout this district the low flat-topped desert hills have a thin capping of hard chalcedonised sandstone, and it is by the disintegration of this rock that the gibbers or stones have been produced. The stony gibber plains merge constantly into loamy plains covered with poor scrub, but on which the gibbers are wanting. It is suggested that these loamy plains occupy areas on which the Upper Cretaceous rocks are not capped with the hard chalcedonised Desert Sandstone, and where, therefore, no gibbers have been formed.

\section{Colours of Animals.}

Some interesting remarks are made by Prof. Spencer on the subject of protective colouration. Prof. Spencer has collected animals in Central Australia, both in the dry season and in the NO. I 4 I 7, VOL. 55] 